\title{
Do enzyme inhibitors dicyandiamide and NBPT influence the microbial immobilization of phosphorus in Humic Cambisol?
}

\author{
Daniel J. Dall'Orsoletta ${ }^{1}$, Luciano C. Gatiboni ${ }^{1}$, Djalma E. Schmitt ${ }^{2}$, Bruna Arruda ${ }^{3}$ \& Joice C. Heidemann ${ }^{4}$ \\ ${ }^{1}$ Universidade do Estado de Santa Catarina/Centro de Ciências Agroveterinárias/Departamento de Solos e Recursos Naturais. Lages, SC. E-mail: \\ dani.orsoletta@gmail.com (Corresponding author) - ORCID: 0000-0003-0882-0073; lgatiboni@gmail.com - ORCID: 0000-0001-8724-3600 \\ ${ }^{2}$ Universidade Federal de Santa Catarina/Centro de Ciências Rurais/Departamento de Agricultura, Biodiversidade e Florestas. Curitibanos, SC. E-mail: \\ djalma.schmitt@gmail.com - ORCID: 0000-0001-9665-9704 \\ ${ }^{3}$ Universidade de São Paulo/Escola Superior de Agricultura Luiz de Queiroz/Departamento de Solos e Nutrição de Plantas. Piracicaba, SP. E-mail: \\ bru_agro@hotmail.com - ORCID: 0000-0001-9264-5591 \\ ${ }^{4}$ Universidade Federal de Viçosa/Departamento de Fitotecnia. Viçosa, MG. E-mail: sunjoyflower@gmail.com - ORCID: 0000-0002-0887-6942
}

\section{Key words:}

soil microbial biomass

pig slurry

nitrification inhibitor

\begin{abstract}
A B S T R A C T
The application of nitrogen fertilizers, both organic and mineral, can cause nitrate losses by leaching. To minimize this effect, enzyme inhibitors are used. However, the effects on microbial biomass, which is the most sensitive and dynamic compartment of nutrients in the soil, as well as its effect on nutrients such as phosphorus (P) are unknown. This study aimed to evaluate the influence of the enzyme inhibitor (EI) on soil microbial phosphorus (Pm) when mineral fertilizer (NPK) or liquid swine manure (LSM) was applied in corn cultivation. The experiment was installed in a Humic Cambisol in Lages - SC, Brazil $\left(27^{\circ}\right.$ 47' 08” S; 50 18' 09" W) in the 2012/2013 season. The treatments consisted of: i) NPK; ii) NPK + EI; iii) LSM; iv) LSM + EI, applied before sowing of corn, and v) control (without application of fertilizer and enzyme inhibitor) arranged in a randomized block design, under no-tillage system. Soil samples were collected from the $0-0.10$ m layer at $0,10,25,58,90$, 135 and 202 days after application of the treatments. The Pm content was not affected by the enzyme inhibitor application but was influenced throughout the crop cycle in response to water balance and corn cultivation.
\end{abstract}

\section{Palavras-chave:}

biomassa microbiana do solo dejeto líquido de suíno inibidor da nitrificação

\section{Inibidores enzimáticos dicianodiamida e NBPT influenciam a imobilização microbiana de fósforo em Cambissolo Húmico?}

\section{R E S U M O}

A aplicação de fertilizantes nitrogenados, tanto orgânicos quanto minerais, pode ocasionar perdas de nitrato por lixiviação. Para minimizar este efeito, inibidores enzimáticos são utilizados. Entretanto, são desconhecidos seus efeitos sobre o acúmulo de nutrientes, como o fósforo (P) da biomassa microbiana, que é o mais sensível e dinâmico compartimento de nutrientes do solo. Objetivou-se avaliar a influência da aplicação de inibidor enzimático (IE) sobre o teor de fósforo da biomassa microbiana do solo (Pm), quando aplicado adubo mineral (NPK) ou dejeto líquido de suínos (DLS) no cultivo de milho. O experimento foi instalado em um Cambissolo Húmico em Lages - SC ( $27^{\circ} 47^{\prime} 08^{\prime \prime}$ S 50 $\left.18^{\prime} 09^{\prime \prime} \mathrm{O}\right)$ na safra de 2012/2013. Os tratamentos foram constituídos de: i) NPK; ii) NPK + IE; iii) DLS; iv) DLS + IE, aplicados antecedendo a semeadura do milho e v) controle (sem aplicação de fertilização e de inibidor enzimático) dispostos em delineamento de blocos casualizados com 4 repetições, em sistema de plantio direto. Amostras de solo foram coletadas da camada $0-0,10 \mathrm{~m}$ de profundidade aos $0,10,25,58,90,135$ e 202 dias após a aplicação dos tratamentos. O teor de Pm não foi afetado pela aplicação de inibidores enzimáticos mas sofreu influência ao longo do ciclo da cultura em resposta ao balanço hídrico e cultivo do milho. 


\section{INTRODUCTION}

In an attempt to reduce nitrogen $(\mathrm{N})$ losses through ammonia volatilization and nitrate leaching, the use of enzyme inhibitors (EI) such as N-(n-butyl) thiophosphoric triamide (NBPT) and dicyandiamide (DCD) has been shown to be viable (Zaman et al., 2009; Dall'Orsoletta et al., 2017). Thus, the addition of these EI in mineral and organic fertilizers has been studied to evalluate the mitigation of these losses and their effect on the yields of crops (Alves et al., 2017; Rauber et al., 2017).

Organic fertilization adds to the soil, besides macroand micronutrients that are essential for plant development (Lourenzi et al., 2013), carbonic compounds which act as stimulants of microbial activity (Bünemann et al., 2004; Singh et al., 2016). Several works have focused on understanding the effects of utilization of enzyme inhibitors on the microbial community and their participation in $\mathrm{N}$ cycle (O'Callaghan et al., 2010; Guo et al., 2013). Nonetheless, studies focusing on the effects of $\mathrm{P}$ from the microbial biomass are scarce in the literature.

Soil microbial biomass is responsible for the mineralization of organic compounds, being directly involved in geochemical cycles of C, N and P (Cleveland \& Liptzin, 2007; Turner et al., 2013; Singh et al., 2016), but is affected by abiotic factors such as temperature, humidity and availability of nutrients (Gatiboni et al., 2008; Bünemann et al., 2013; Turner et al., 2013). Thus, concomitant use of both inhibitors (DCD and NBPT), since they maintain $\mathrm{N}$ in less available forms, can be limiting to soil microorganisms (Mooshammer et al., 2014).

In this context, it is hypothesized that the use of enzyme inhibitors, DCD and NBPT, can affect the microbial immobilization of $\mathrm{P}$, especially when they are added with mineral fertilizers. This study aimed to evaluate the influence of enzyme inhibitor addition on the dynamics of soil microbial $\mathrm{P}$ and its interaction with the use of organic and mineral fertilization, during corn cultivation in a no-tillage system.

\section{Material ANd Methods}

The experiment was conducted in experimental area

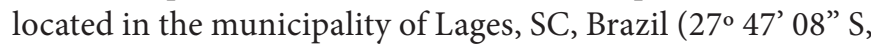
$50^{\circ} 18^{\prime} 09^{\prime \prime} \mathrm{W}$ ), which has humid mesothermal climate, $\mathrm{Cfb}$, according to Köppen's classification. Mean annual precipitation is $1400 \mathrm{~mm}$ and the mean temperature is $15.6{ }^{\circ} \mathrm{C}$.

The experiment was installed in a typic Aluminic Humic Cambisol (EMBRAPA, 2013), with the following physical and chemical attributes, in the 0-0.20 m layer: clay and organic matter of 455 and $46 \mathrm{~g} \mathrm{~kg}^{-1}$, respectively; $\mathrm{pH}-\mathrm{H}_{2} \mathrm{O}$ of 5.4, pH-SMP of 5.9; $\mathrm{Al}^{3+}, \mathrm{Ca}^{2+}, \mathrm{Mg}^{2+}$ and CEC of 1.5; 5.6; 1.9 and $12.7 \mathrm{cmol} \mathrm{dm}^{-3}$, respectively; available $\mathrm{P}$ and $\mathrm{K}$ of 3.1 and $92 \mathrm{mg} \mathrm{dm}^{-3}$, respectively, and base saturation of $61 \%$, analyzed according to Tedesco et al. (1995).

Treatments were: i) mineral fertilization (NPK); ii) NPK + enzyme inhibitors dicyandiamide and NBPT (EI); iii) liquid swine manure (LSM); iv) LSM + EI and v) control (without application of fertilizer and EI). The experiment was set up in randomized blocks, with four replicates and $33.6 \mathrm{~m}^{2}$ experimental units. In treatments with mineral source NPK, $130 \mathrm{~kg} \mathrm{ha}^{-1}$ of $\mathrm{N}, 185 \mathrm{~kg} \mathrm{ha}^{-1}$ of $\mathrm{P}_{2} \mathrm{O}_{5}$ and $70 \mathrm{~kg} \mathrm{ha}^{-1}$ of $\mathrm{K}_{2} \mathrm{O}$ were applied as urea, triple superphosphate and potassium chloride, respectively. In treatments with organic source, $42 \mathrm{~m}^{3} \mathrm{ha}^{-1}$ of LSM, totaling $130 \mathrm{~kg} \mathrm{ha}^{-1}$ of N, $251 \mathrm{~kg} \mathrm{ha}^{-1}$ of $\mathrm{P}_{2} \mathrm{O}_{5}$ and $65 \mathrm{~kg} \mathrm{ha}^{-1}$ of $\mathrm{K}_{2} \mathrm{O}$ were applied, respectively, based on the recommendations of CQFS (2004) for an expected yield of $8 \mathrm{Mg} \mathrm{ha}^{-1}$ of corn grains.

The EI, at dose of $10 \mathrm{~kg} \mathrm{ha}^{-1}$, was mixed with the NPK and with the LSM in the treatments containing EI upon the application in the field. The EI used is formulated by the mixture of DCD and NBPT, with commercial name of Agrotain Plus ${ }^{\circledast}$. The fertilizers were applied in the entire area on the surface and at single dose on the wheat residues, seven days before sowing of corn, in the 2012/2013 season.

Composite soil samples composed of five subsamples were randomly collected with a gouge auger, in the 0-0.10 m layer, on the following dates: 0 (before sowing and application of treatments), 10 (VE: emergence), 25 (V2: two expanded leaves) 58 (VN: until tasseling), 90 (R1: tasseling), 135 (R4: formation of farinaceous grains) and 202 (R6: physiological maturity of corn grains) days after application of treatments (DAA).

Soil samples, still wet, were pounded to break up clods, homogenized, sieved through a $2-\mathrm{mm}$ mesh and kept in cold chamber at $4{ }^{\circ} \mathrm{C}$ until the analysis of $\mathrm{P}$ contained in the microbial biomass $(\mathrm{Pm})$, performed in triplicates. After quantification of $\mathrm{Pm}$, soil samples were dried at $65^{\circ} \mathrm{C}$ in a forced-air oven until constant weight and subjected to analysis of $\mathrm{P}$ extracted by anion exchange resin (P-AER) to determine the available P (Tedesco et al., 1995), labile organic carbon (Labile C) (Blair et al., 1995) and labile nitrogen (Labile N) (Blair et al., 1995), since these are the carbon and nitrogen fractions which are readily available and affected by microbial activity. The Pm content was determined by the fumigationextraction method proposed by Brookes et al. (1982).

Daily climate data of mean temperature and rainfall of Lages, SC, provided by EPAGRI/CIRAM, and solar radiation and soil moisture were used to determine the water balance of the experimental period by the Thornthwaite method as an estimate of soil water availability in the sampling periods.

The obtained data were subjected to Shapiro-Wilk normality test and analysis of variance - ANOVA ( $p<0.05)$, and the significant effects were then compared by Scott-Knott test $(\mathrm{p}<0.05)$, using the statistical program SISVAR (Ferreira, 2011).

\section{Results AND Discussion}

Pm contents did not differ between treatments, except at 202 DAA (Table 1), when the values observed in treatments that received fertilization were higher than those in the control. In the same period, i.e., at $202 \mathrm{DAA}$, higher Pm contents were observed in all treatments.

The available $\mathrm{P}$ extracted by anion exchange resin (P-AER) was not affected by the interaction between sources and sampling periods, only by the factors individually. Over time, P-AER availability increased from 0 DAA until the other periods, including in the control treatment. Considering the 
Table 1. Soil microbial phosphorus $(\mathrm{Pm})$ in the 0-0.10 m layer of a Humic Cambisol cultivated with corn, sampled at seven periods after application of organic or mineral fertilization, with or without enzyme inhibitors (EI)

\begin{tabular}{|c|c|c|c|c|c|c|c|}
\hline \multirow{2}{*}{$\begin{array}{l}\text { Phenological } \\
\text { stage }\end{array}$} & \multirow{2}{*}{ DAA } & NPK & NPK + EI & LSM & $\mathrm{LSM}+\mathrm{EI}$ & CTRL & Mean \\
\hline & & \multicolumn{6}{|c|}{$\mathrm{Pm}\left(\mathrm{mg} \mathrm{kg}^{-1}\right)$} \\
\hline- & 0 & $38.1 \mathrm{aD}$ & $38.1 \mathrm{aE}$ & $35.5 \mathrm{aC}$ & $34.3 \mathrm{aC}$ & $39.1 \mathrm{aB}$ & 37.0 \\
\hline VE & 10 & $60.3 \mathrm{aC}$ & $54.0 \mathrm{aD}$ & $67.5 \mathrm{aB}$ & $51.8 \mathrm{aC}$ & $44.6 \mathrm{aB}$ & 55.6 \\
\hline V2 & 24 & $50.1 \mathrm{aD}$ & $58.9 \mathrm{aD}$ & $48.3 \mathrm{aC}$ & $54.3 \mathrm{aC}$ & $46.3 \mathrm{aB}$ & 51.6 \\
\hline VN & 58 & $44.2 \mathrm{aD}$ & $40.9 \mathrm{aE}$ & $44.2 \mathrm{aC}$ & $45.6 \mathrm{aC}$ & $53.1 \mathrm{aB}$ & 45.6 \\
\hline R1 & 90 & $81.2 \mathrm{aB}$ & $83.4 \mathrm{aB}$ & $76.6 \mathrm{aB}$ & $77.6 \mathrm{aB}$ & $99.0 \mathrm{aA}$ & 83.6 \\
\hline R4 & 135 & $65.0 \mathrm{aC}$ & $65.6 \mathrm{aC}$ & $59.5 \mathrm{aB}$ & $72.4 \mathrm{aB}$ & $58.5 \mathrm{aB}$ & 64.2 \\
\hline \multirow[t]{2}{*}{ R6 } & 202 & $113.9 \mathrm{aA}$ & $127.1 \mathrm{aA}$ & $122.0 \mathrm{aA}$ & $110.7 \mathrm{aA}$ & $88.2 \mathrm{bA}$ & 112.4 \\
\hline & Mean & 64.7 & 66.8 & 64.8 & 63.8 & 61.3 & \\
\hline
\end{tabular}

DAA - Days after application of treatments; NPK - Mineral fertilization; NPK + El - Mineral fertilization plus enzyme inhibitor; LSM - Liquid swine manure; LSM + EI - Liquid swine manure plus enzyme inhibitor; CTRL - Control without fertilization; VE - Emergence; V2 - Two expanded leaves; VN - Until tasseling; R1 - Tasseling; R4 - Farinaceous grain; R6 - Physiological maturity; CV - Coefficient of variation; Same letters, lowercase in the row and uppercase in the column, do not differ by Scott-Knott test $(p<0.05)$

effect of treatments, regardless of the time, all treatments that received fertilization were superior to the control with respect to P-AER (Table 2).

Both Labile $\mathrm{C}$ and Labile $\mathrm{N}$ were affected by the interaction between treatments and sampling periods. For Labile $C$, the means at the time of sowing were $1.4 \mathrm{~g} \mathrm{~kg}^{-1}$, and its values increased soon after LSM application. On the other hand, at 90 DAA (tasseling stage), there were no differences between

Table 2. Available phosphorus extracted by anion exchange resin (P-AER), labile carbon (Labile $\mathrm{C}$ ) and labile nitrogen (Labile N), in the 0-0.10 m layer of a Humic Cambisol cultivated with corn, sampled at seven periods after application of organic or mineral phosphate fertilization, with or without enzyme inhibitors (EI)

\begin{tabular}{|c|c|c|c|c|c|c|}
\hline DAA & NPK & NPK + EI & LSM & LSM + EI & CTRL & Mean \\
\hline & \multicolumn{6}{|c|}{ P-AER (mg kg-1) } \\
\hline 0 & 34.0 & 52.1 & 41.9 & 43.7 & 39.3 & $42.2 \mathrm{~B}$ \\
\hline 10 & 129.5 & 138.6 & 131.0 & 88.1 & 37.2 & $104.9 \mathrm{~A}$ \\
\hline 24 & 101.9 & 143.2 & 79.5 & 49.5 & 41.3 & $83.1 \mathrm{~A}$ \\
\hline 58 & 126.9 & 109.2 & 127.8 & 122.0 & 78.9 & $113.0 \mathrm{~A}$ \\
\hline 90 & 117.2 & 117.2 & 102.5 & 86.4 & 71.8 & $99.0 \mathrm{~A}$ \\
\hline 135 & 101.0 & 104.4 & 94.8 & 86.2 & 47.4 & $86.8 \mathrm{~A}$ \\
\hline 202 & 147.4 & 102.7 & 126.2 & 102.8 & 51.2 & $106.1 \mathrm{~A}$ \\
\hline Mean & $108.3 \mathrm{a}$ & $109.6 \mathrm{a}$ & $100.5 \mathrm{a}$ & $82.7 \mathrm{a}$ & $52.4 \mathrm{~b}$ & \\
\hline \multicolumn{7}{|c|}{ CV $36.50 \%$} \\
\hline \multicolumn{7}{|c|}{ Labile C $\left(\mathrm{g} \mathrm{kg}^{-1}\right)$} \\
\hline 0 & $1.9 \mathrm{aB}$ & $1.1 \mathrm{aC}$ & $1.2 \mathrm{aB}$ & $1.3 \mathrm{aB}$ & $1.8 \mathrm{aB}$ & 1.4 \\
\hline 10 & $1.5 \mathrm{bB}$ & $2.4 \mathrm{bB}$ & $3.7 \mathrm{aA}$ & $3.8 \mathrm{aA}$ & $2.0 \mathrm{bB}$ & 2.7 \\
\hline 24 & $3.0 \mathrm{bA}$ & $4.8 \mathrm{aA}$ & $2.0 \mathrm{bB}$ & $2.7 \mathrm{bA}$ & $2.3 \mathrm{bB}$ & 3.0 \\
\hline 58 & $2.2 \mathrm{bA}$ & $4.5 \mathrm{aA}$ & $1.3 \mathrm{bB}$ & $1.3 \mathrm{bB}$ & $0.9 \mathrm{bB}$ & 2.0 \\
\hline 90 & $0.8 \mathrm{aB}$ & $1.3 \mathrm{aC}$ & $1.4 \mathrm{aB}$ & $2.1 \mathrm{aB}$ & $1.8 \mathrm{aB}$ & 1.5 \\
\hline 135 & $1.8 \mathrm{bB}$ & $1.7 \mathrm{bC}$ & $2.9 \mathrm{aA}$ & $3.2 \mathrm{aA}$ & $2.7 \mathrm{aA}$ & 2.5 \\
\hline 202 & $3.1 \mathrm{aA}$ & $3.0 \mathrm{aB}$ & $3.4 \mathrm{aA}$ & $3.7 \mathrm{aA}$ & $3.5 \mathrm{aA}$ & 3.2 \\
\hline Mean & 2.0 & 2.7 & 2.3 & 2.6 & 2.1 & \\
\hline \multicolumn{7}{|c|}{ CV $33.42 \%$} \\
\hline \multicolumn{7}{|c|}{ Labile $\mathrm{N}\left(\mathrm{mg} \mathrm{kg}^{-1}\right)$} \\
\hline 0 & $33.3 \mathrm{bB}$ & $47.5 \mathrm{aA}$ & $39.5 \mathrm{aA}$ & $44.0 \mathrm{aA}$ & $27.8 \mathrm{bA}$ & 38.4 \\
\hline 10 & $45.3 \mathrm{aA}$ & $42.0 \mathrm{aA}$ & $36.5 \mathrm{bA}$ & $34.8 \mathrm{bB}$ & $21.5 \mathrm{cB}$ & 36.0 \\
\hline 24 & $22.0 \mathrm{aC}$ & $23.5 \mathrm{aC}$ & $26.0 \mathrm{aB}$ & $22.8 \mathrm{aB}$ & $21.5 \mathrm{aB}$ & 23.2 \\
\hline 58 & $28.3 \mathrm{aC}$ & $31.3 \mathrm{aB}$ & $14.3 \mathrm{bC}$ & $13.0 \mathrm{bC}$ & $14.0 \mathrm{bB}$ & 20.2 \\
\hline 90 & $12.0 \mathrm{aD}$ & $18.8 \mathrm{aC}$ & $19.0 \mathrm{aC}$ & $19.8 \mathrm{aB}$ & $19.5 \mathrm{aB}$ & 17.8 \\
\hline 135 & $19.5 \mathrm{aC}$ & $19.3 \mathrm{aC}$ & $18.3 \mathrm{aC}$ & $21.0 \mathrm{aB}$ & $19.8 \mathrm{aB}$ & 19.6 \\
\hline 202 & $23.0 \mathrm{aC}$ & $26.0 \mathrm{aB}$ & $26.0 \mathrm{aB}$ & $26.3 \mathrm{aB}$ & $27.0 \mathrm{aA}$ & 25.7 \\
\hline Mean & 26.2 & 29.8 & 25.6 & 25.9 & 21.6 & \\
\hline
\end{tabular}

DAA - Days after application of treatments; NPK - Mineral fertilization; NPK + El - Mineral fertilization plus enzyme inhibitors; LSM - Liquid swine manure; LSM + El - Liquid swine manure plus enzyme inhibitors; CTRL - Control without fertilization; CV - Coefficient of variation; Same letters, lowercase in the row and uppercase in the column, do not differ by Scott-Knott test $(p<0.05)$ treatments. However, when the grains were already formed, at $135 \mathrm{DAA}$ (R4 stage), Labile C increased only where organic fertilizers were applied. However, at 202 DAA (physiological maturity), Labile $\mathrm{C}$ values were again equal between treatments.

Application of EI did not affect the contents of Labile $\mathrm{N}$ in the soil, and this parameter was only affected by the source of nutrients. In the treatments with inorganic sources of fertilizer, Labile $\mathrm{N}$ contents were higher than the others at 10 and $58 \mathrm{DAA}$, and only at 10 DAA the treatments with organic fertilization were superior to the control. In general, Labile $\mathrm{C}$ and Labile $\mathrm{N}$ showed similar behavior, with an increment after the treatments were applied (10 and 24 DAA), followed by a decline at 90 DAA and increase at 202 DAA (Table 2).

For Pm, the general behavior was an increase until 90 DAA with reduction at $135 \mathrm{DAA}$ and subsequent increase at 202 DAA (Figure 1). The magnitude of the increase in Pm contents followed the water balance of the area, which became positive only after $24 \mathrm{DAA}$, remaining between 150 and $50 \mathrm{~mm}$ at 58 and 202 DAA, respectively. In general, from 58 DAA on, period with no water restriction, the highest values of Pm were observed, above $60 \mathrm{mg} \mathrm{kg}^{-1}$, for the fertilized treatments (Figure 1).

The addition of EI, applied along with an either organic or mineral source of fertilizer, did not affect $\mathrm{P}$ immobilization

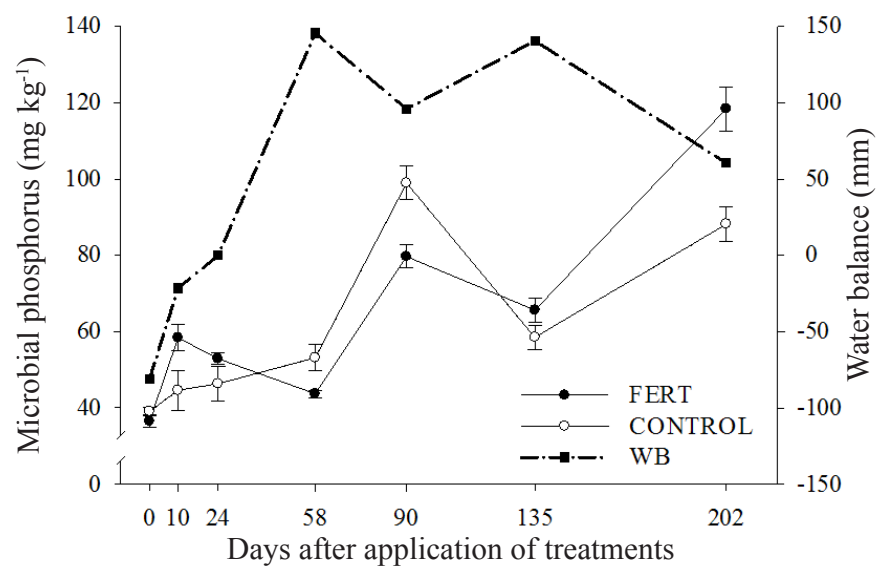

Bars represent the standard error of the observations

Figure 1. Soil microbial phosphorus, mean of the plots with fertilization (FERT) and without fertilization (CONTROL), in the $0-0.10$ m layer of a Humic Cambisol, and water balance (WB) as a function of days after application of treatments, determined by the Thornthwaite method 
by soil microbial biomass. Studies on the influence of EI application on the accumulation of nutrients in microbial communities also found no reduction in the contents of other nutrients, such as $\mathrm{N}$ and C (O'Callaghan et al., 2010), even after long periods with applications (Guo et al., 2013).

The specificity of EI, DCD and NBPT in the action on the enzymes ammonia monooxygenase and urease, respectively (Zaman et al., 2009; O’Callaghan et al., 2010; Guo et al., 2013), and their short residence time in the soil, not more than 30 days after application (Kelliher et al., 2008), can justify the lack of effect on the accumulation of nutrients by the microbial biomass (Zaman et al., 2009; O'Callaghan et al., 2010; Guo et al., 2013), including $P$.

However, despite not being influenced by the sources of nutrients, Pm was affected by the environmental condition in the sampling period and by the physiological stage of corn. Lowest contents of P-AER and Pm were found at the beginning of the experimental period (0 DAA). Lower P availability, as observed in this period, favors the mineralization process instead of microbial immobilization (Gatiboni et al., 2008; Heuck et al., 2015).

In addition, the periods with lowest Pm contents, from 0 to $58 \mathrm{DAA}$ and $135 \mathrm{DAA}$, coincide with periods in which water balance was either negative or very high (Figure 1). In periods of water stress, microorganisms die and cell lysis occurs, releasing in the solution organic and inorganic forms of $\mathrm{P}$ which are subject to absorption by plants, adsorption in the soil or microbial immobilization (Bünemann et al., 2013). Conversely, conditions of soil saturation lead to reduction and modification of the microbial community (Unger et al., 2009).

Maximum values of Pm are observed in all treatments at 202 DAA, at the R6 stage, physiological maturity. At this stage, besides the full stop in the accumulation of dry matter in the grains, the natural process of senescence also begins in the plant, resulting in supply of N, C and P for microbial activity, which in turn immobilizes larger quantities of $\mathrm{P}$ (Bünemann et al., 2013; Damon et al., 2014; Heuck et al., 2015; Singh et al., 2016).

The application of EI did not affect soil P availability; however, P-AER contents increased in treatments with application of fertilizers. Plants and microorganisms have mechanisms that can provide $\mathrm{P}$, such as the exudation of enzymes (Gatiboni et al., 2008; Richardson \& Simpson, 2011; Turner \& Wright, 2014). Nevertheless, these mechanisms were not sufficient or even necessary to exert influence on P-AER contents, because even in the control treatment its levels were high (> $20 \mathrm{mg} \mathrm{dm}^{-3}$ ) (CQFS, 2004) along the entire period.

As observed for the other variables evaluated, application of EI had no effect on Labile $\mathrm{C}$ and Labile $\mathrm{N}$, but these parameters were affected by the source of nutrient used and by the sampling period. The application of soluble NPK fertilizer increased Labile $\mathrm{N}$ contents in the first sampling after application (from 33.3 to $45.3 \mathrm{mg} \mathrm{kg}^{-1}$ ), probably because it releases large amount of ammonium in the soil (Rauber et al., 2017; Dall'Orsoletta et al., 2017).

On the other hand, the application of organic source increased Labile $C$ contents in the first sampling after application (10 DAA) and at the same time led to Labile $\mathrm{N}$ contents that were lower compared with the soluble fertilizers at $10 \mathrm{DAA}$ (NPK and NPK+EI) and higher compared with the control. Under this condition, probably due to the addition of carbonic compounds, part of the Labile-N was immobilized by the microbial biomass in the mineralization process (Mooshammer et al., 2014).

This same effect can be observed in the last samplings, in which the increase in Labile $\mathrm{C}$ due to the beginning of plant senescence is followed by a reduction in Labile- $\mathrm{N}$. Successive applications of organic/inorganic fertilizers tend to increase microbial activity, directly through the supply of $\mathrm{C}$ and nutrients, and indirectly through the increment in plant production and improvements in soil physical and chemical conditions (Bünemann et al., 2004, 2013; Simpson et al., 2011; Lourenzi et al., 2013).

The results in the present study demonstrate that the addition of EI has no marked effect on Pm immobilization and other variables evaluated. However, the source of fertilizer used and the environmental conditions exert influence on these variables. In a study in the same area, Alves et al. (2017) also found no effect of EI addition on corn grain yield and dry matter. Thus, the utilization of EI under these conditions should be questioned, and more research efforts are needed to elucidate its viability.

\section{Conclusions}

1. The utilization of enzyme inhibitors dicyandiamide and $\mathrm{N}$-(n-butyl) thiophosphoric triamide does not change the contents of soil microbial phosphorus, regardless of being applied along with either mineral or organic source of nutrients.

2. Immobilization of soil microbial phosphorus was not influenced by the source of nutrients, either organic or mineral.

3. Immobilization of soil microbial phosphorus is influenced by water balance, decreasing under conditions of water deficit or excess.

\section{Literature Cited}

Alves, C. T. de F.; Cassol, P. C.; Sacomori, W.; Gatiboni, L. C.; Ernani, P. R.; Aita, C.; Panisson, J.; Ferreira, A. K. T. Influência da adubação com dejeto suíno e adubo mineral adicionada de inibidor de nitrificação sobre a produtividade e a nutrição do milho. Revista de Ciências Agroveterinárias, v.16, p.02-10, 2017.

Blair, G. J.; Lefroy, R. D. B.; Lisle, L. Soil carbon fractions, based on their degree of oxidation, and the development of a carbon management index for agricultural systems. Australian Journal of Agricultural Research, v.46, p.1459-1466, 1995. https:/doi. org/10.1071/AR9951459

Brookes, P. C.; Powlson, D. S.; Jenkinson, D. S. Measurement of microbial biomass phosphorus in soil. Soil Biology and Biochemistry, v.14, p.319-329, 1982. https://doi.org/10.1016/00380717(82)90001-3

Bünemann, E. K.; Keller, B.; Hoop, D.; Jud, K.; Boivin, P.; Frossard, E. Increased availability of phosphorus after drying and rewetting of a grassland soil: Processes and plant use. Plant Soil, v.370, p.511526, 2013. https://doi.org/10.1007/s11104-013-1651-y 
Bünemann, E. K.; Steinebrunner, F.; Smithson, P. C.; Frossard, E.; Oberson, A. A. Phosphorus dynamics in a highly-weathered soil as revealed by isotopic labeling techniques. Soil Science Society of America Journal, v.68, p.1645-1655, 2004. https://doi.org/10.2136/ sssaj2004.1645

Cleveland, C. C.; Liptzin D. C:N:P stoichiometry in soil: Is there a "redfield ratio" for the microbial biomass? Biochemistry, v.85, p.235-252, 2007. https://doi.org/10.1007/s10533-007-9132-0

CQFS - Comissão de Química e Fertilidade do Solo - RS/SC. Manual de adubação e de calagem para os estados do Rio Grande do Sul e Santa Catarina. 10.ed. Porto Alegre: CQFS, 2004. 400p.

Dall'Orsoletta, D. J.; Rauber, L. P.; Schmitt, D. E.; Gatiboni, L. C.; Orsolin, J. Urea coated with poultry litter as an option in the control of nitrogen losses. Revista Brasileira de Engenharia Agrícola e Ambiental, v.21, p. 398-403, 2017. https://doi. org/10.1590/1807-1929/agriambi.v21n6p398-403

Damon, P. M.; Bowden, B.; Rose, T.; Rengel, Z. Crop residue contributions to phosphorus pools in agricultural soils: A review. Soil Biology and Biochemistry, v.74, p.127-137, 2014. https://doi. org/10.1016/j.soilbio.2014.03.003

EMBRAPA - Empresa Brasileira de Pesquisa Agropecuária. Sistema brasileiro de classificação de solos. 3.ed. rev. ampl. Brasília: Embrapa Informação Tecnológica, 2013. 353p.

Ferreira, D. F. Sisvar: A computer statistical analysis system. Ciência e Agrotecnologia, v.35, p.1039-1042, 2011. https://doi.org/10.1590/ S1413-70542011000600001

Gatiboni, L. C.; Kaminski, J.; Rheinheimer, D. dos S. Fósforo da biomassa microbiana e atividade de fosfatases ácidas durante a diminuição do fósforo disponível no solo. Pesquisa Agropecuária Brasileira, v.43, p.1085-1091, 2008. https://doi.org/10.1590/ S0100-204X2008000800019

Guo, Y. J.; Di, H. J.; Cameron, K. C.; Li, B.; Podolyan, A.; Moir, J. L.; Monaghan, R. M.; Smith, L. C.; O’Callaghan, M.; Bowatte, S.; Waugh, D.; He, J. Effect of 7-year application of a nitrification inhibitor, dicyandiamide, on soil microbial biomass, protease and deaminase activities, and the abundance of bacteria and archaea in pasture soils. Journal of Soils and Sediments, v.13, p.753-759, 2013. https://doi.org/10.1007/s11368-012-0646-2

Heuck, C.; Weig, A.; Spohn, M. Soil microbial biomass C:N:P stoichiometry and microbial use of organic phosphorus. Soil Biology and Biochemistry, v.85, p.119-129, 2015. https://doi. org/10.1016/j.soilbio.2015.02.029

Kelliher, F. M.; Clough, T. J.; Clark, H.; Rys, G.; Sedcole, J. R. The temperature dependence of dicyandiamide degradation in soils: A data synthesis. Soil Biology and Biochemistry, v.40, p.1878-1882, 2008. https://doi.org/10.1016/j.soilbio.2008.03.013

Lourenzi, C. R.; Ceretta, C. A.; Silva, L. da S.; Girotto, E.; Lorensini, F.; Tiecher, T. L.; Conti, L. de; Trentin, G.; Brunetto, G. Nutrients in soil layers under no-tillage after successive pig slurry applications. Revista Brasileira de Ciência do Solo, v.37, p.157-167, 2013. https://doi.org/10.1590/S0100-06832013000100016
Mooshammer, M.; Wanek, W.; Hämmerle, I.; Fuchslueger, L.; Hofhansl, F.; Knoltsch, A.; Schnecker, J.; Takriti, M.; Watzka, M.; Wild, B.; Keiblinger, K. M.; Zechmeister-Boltenstern, S.; Richter, A. Adjustment of microbial nitrogen use efficiency to carbon:nitrogen imbalances regulates soil nitrogen cycling. Nature Communications, v.5, p.1-7, 2014. https://doi.org/10.1038/ncomms4694

O’Callaghan, M.; Gerard, E. M.; Carter, P. E.; Lardner, R.; Sarathchandra, U.; Burch, G.; Ghani, A.; Bell, N. Effect of the nitrification inhibitor dicyandiamide (DCD) on microbial communities in a pasture soil amended with bovine urine. Soil Biology and Biochemistry, v.42, p.1425-1436, 2010. https://doi.org/10.1016/j.soilbio.2010.05.003

Rauber, L. P.; Andrade, A. P.; Santos, W. B.; Mafra, Á. L.; Andreola, A; Gatiboni, L. C. Ammonia volatilization with swine slurry injection and use of nitrification inhibitor. Revista Ceres, v.64, p.307-314, 2017. https://doi.org/10.1590/0034-737x201764030012

Richardson, A. E.; Simpson, R. J. Soil microorganisms mediating phosphorus availability update on microbial phosphorus. Plant Physiology, v.156, p.989-996, 2011. https://doi.org/10.1104/ pp.111.175448

Simpson, R. J.; Oberson, A.; Culvenor, R. A.; Megan, H. R.; Veneklaas, E. J.; Lambers, H.; Lynch, J. P.; Ryan, P. R.; Delhaize, E.; Smith, F. A.; Smith, S. E.; Harvey, P. R.; Richardson, A. E. Strategies and agronomic interventions to improve the phosphorus-use efficiency of farming systems. Plant Soil, v.349, p.89-120, 2011. https://doi.org/10.1007/s11104-011-0880-1

Singh, A.; Singh, M. K.; Ghoshal, N. Microbial biomass dynamics in a tropical agroecosystem: Influence of herbicide and soil amendments. Pedosphere, v.26, p.257-264, 2016. https://doi. org/10.1016/S1002-0160(15)60040-6

Tedesco, M. J.; Gianello, C.; Bissani, C. A.; Bohnen, H.; Volkweiss, S. J. Análise de solo, plantas e outros materiais. 2.ed. rev. ampl. Porto Alegre: UFRGS, 1995. 174p. Boletim Técnico, 5

Turner, B. L.; Lambers, H.; Condron, L. M.; Cramer, M. D.; Leake, J. R.; Richardson, A. E.; Smith, S. E. Soil microbial biomass and the fate of phosphorus during long-term ecosystem development. Plant Soil, v.367, p.225-234, 2013. https://doi.org/10.1007/s11104012-1493-Z

Turner, B. L.; Wright, J. S. The response of microbial biomass and hydrolytic enzymes to a decade of nitrogen, phosphorus, and potassium addition in a lowland tropical rain forest. Biochemistry, v.117, p.115-130, 2014. https://doi.org/10.1007/s10533-0139848-y

Unger, I. M.; Kennedy, A. C.; Muzika, R. M. Flooding effects on soil microbial communities. Applied Soil Ecology, v.42, p.1-8, 2009. https://doi.org/10.1016/j.apsoil.2009.01.007

Zaman, M.; Saggar, S.; Blennerhassett, J. D.; Singh, J. Effect of urease and nitrification inhibitors on $\mathrm{N}$ transformation, gaseous emissions of ammonia and nitrous oxide, pasture yield and $\mathrm{N}$ uptake in grazed pasture system. Soil Biology and Biochemistry, v.41, p.1270-1280, 2009. https://doi.org/10.1016/j. soilbio.2009.03.011 